\title{
Modeling of Water Transportation in Dynamic Load Proton Exchange Membrane (PEM) Fuel Cell Power Generator
}

\author{
Agung Bakhtiar* Choi, Kwang-Hwan** Kim, Young-Bok*** \\ *Graduate School of Regeneration and Air Conditioning Engineering, Pukyong National University, \\ **Dept. of Regeneration and Air Conditioning Engineering, Pukyong National University, \\ ***Department of Mechanical System Engineering, Pukyong National University(choikh@pknu.ac.kr)
}

\section{동적부하 PEM 연료전지 발전기에 있어서의 수분전달 모델링}

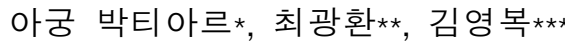

*냉동공조공학과 대학원, 부경대학교, **냉동공조공학과, 공과대학, 부경대학교, ***기계시스템공학과, 공과대학, 부경대학교(choikh@pknu.ac.kr)

\begin{abstract}
$\mathrm{PEM}$ 연료전지에 있어서 수분의 균형이 연료전지의 시스템 성능에 현저한 영향을 미친다. 그래서 수분 균형은 가장 중요한 요소 중의 일부가 되었으며, 이에 관한 연구가 광범위하게 이루어지고 있다. 적절한 수분 균형을 유지하기 위해 서는 적당한 멤브레인 수화작용(membrane hydration)이 필요하며, 반대로 촉매층(catalyst layer)에서의 익수(water flooding)현상이 없어져야 한다. 따라서 이와 같은 동적 상태에서 PEM 연료전지 내의 수분 균형을 유지하기 위해서는, 고도의 동적 수분 조정 기술이 확보되어야 한다. 현재의 연구는 이러한 특성을 고려하여 PEM 연료전지에서 동적부하 상태에서의 수분 이동에 관한 일차원 해석 모델에 관한 것이다. 금번 모델링의 결과, 양극촉매층(CCL, cathode catalyst layer)에서의 수분 상태는 거의 포화 단계에 이르고 있음을 보여주고 있으며, 이 모델링은 연료전지가 작동되 는 동안의 CCL에 나타나는 수분의 양상을 예측하는데 활용될 수 있다. 본 논문에서는 수분 이동 모델이 국제규격에 따라 다양한 수송기관이 가동될 때, 동적부하 상태에서 서로 다른 차이점을 발견하기 위한 시뮬레이션 결과에 초점이 맞추어져 있다. 이 모델링을 적용한 결과, 수분 포화도가 상태에 따라 상이하게 나타남을 알 수 있었고, 또한 정적 수분 조절 요소에 따라 최적 상태가 모든 동적 분포에 따라 달라짐을 알 수 있었다.
\end{abstract}

Keywords : Fuel cell, Model, Dynamic, Water transport, Driving Cycle, Membrane

투고일자 : 2011년 1월 5일, 심사일자 : 2011년 2월 25일, 게재확정일자 : 2011년 4월 13일

교신저자 : 최광환(choikh@pknu.ac.kr) 


\section{Nomenclature}

$\dot{n} \quad$ : molar rate $\left(\right.$ mol.s ${ }^{-1}$ )

$c_{d} \quad$ : electro osmotic drag coefficient

p : density $\left(\mathrm{kg} . \mathrm{cm}^{-3}\right)$

$M_{r} \quad$ : relative molecular mass $(\mathrm{kg} / \mathrm{mol})$

$\kappa \quad$ : permeability $\left(\mathrm{m}^{2}\right)$

$\mathrm{s} \quad$ : liquid saturation level

$\varepsilon \quad:$ porosity

$\mu \quad$ : dynamic Viscosity $\left(\mathrm{m}^{2} \cdot \mathrm{s}^{-1}\right)$

$T$ : temperature $\left({ }^{\circ} \mathrm{C}\right)$

$\delta \quad:$ thickness $(\mathrm{m})$

$\lambda \quad:$ latent heat $\left(\mathrm{kJ} \cdot \mathrm{kg}^{-1}\right)$

$h \quad$ : heat transfer coefficient

$h \quad\left(\mathrm{~W} . \mathrm{m}^{-2} \mathrm{~K}^{-1}\right)$

$c_{\text {drag }}$ : air resistance constant

$a \quad:$ acceleration $\left(\mathrm{m} \cdot \mathrm{s}^{-2}\right)$

$v \quad$ : vehicle velocity $\left(\mathrm{m} \cdot \mathrm{s}^{-1}\right)$

$C R F$ : rolling resistance coefficient

$I \quad$ : current density $\left({\mathrm{A} . \mathrm{m}^{-2}}^{2}\right)$

$A:$ cross section area, $\left(\mathrm{m}^{2}\right)$

$F \quad:$ Faraday constant $\left(\mathrm{C}^{\mathrm{mol}}{ }^{-1}\right)$

$\phi \quad:$ humidity ratio $(\mathrm{g} / \mathrm{kg})$

$m$ : mass (kg)

$\gamma:$ specific volume $\left(\mathrm{m}^{3} / \mathrm{kg}\right)$

$V \quad:$ volume $\left(\mathrm{m}^{3}\right)$

$Q$ : flow rate $\left(\mathrm{m}^{3} / \mathrm{s}\right)$

$W \quad$ : power (Watt)

\section{Subscript}

$\begin{array}{ll}\text { cap } & \text { : capillarity } \\ \text { evap } & \text { : evaporation } \\ \text { rct } & \text { : reaction } \\ \text { sat } & \text { : saturated } \\ \text { liq } & \text { : liquid } \\ \text { vap } & \text { : vapor } \\ \text { ve } & \text { : vehicle }\end{array}$

\section{Introduction}

Generally, flooding of a cathode catalyst layer (CCL) in Fuel cell is linked to high current density operation, which results in the increase of water production rate higher than the removal rate. However, flooding can also occur at low current densities under certain operating conditions, such as low temperatures and low gas flow rates in which faster saturation of the gas phase by water vapor [1] can occur. Therefore, water management is a critical design consideration for PEM fuel cell systems. The amount and disposition of water within the fuel cell strongly affect efficiency and reliability [2].

The purpose of this paper is to propose the water transportation model to get the advanced water management in PEM fuel cell. This study also simulates the model using dynamic load from several standard driving cycles to test the performances.

\section{Model}

Water balance in cathode catalyst layer (CCL) is based on the different amount between the rate of water addition and removal as shown in Fig 1.

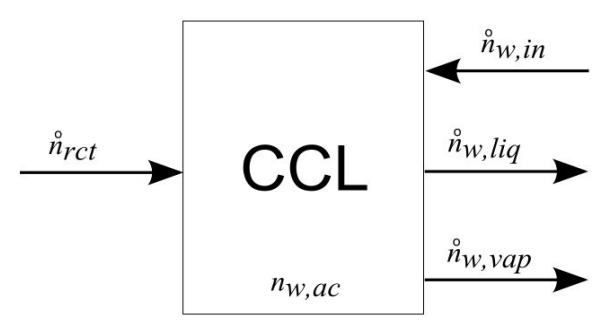

Fig 1. Water balance in CCL.

The water addition in CCL can be simplify expressed as the total of the water production from oxygen reduction reaction (ORR) and electro osmotic transportation as formulated in Eq. 1 [3]. 


$$
n_{r c t}=\left(c_{d}+1\right) \frac{I A}{2 F}
$$

The input air also contains water that is carried from the humidity. Therefore, the water addition from humid air is given by Eq. 2[4].

$$
\dot{n}_{w, i n}=\frac{\phi Q}{\gamma M_{r}}
$$

The water removal can be occurred in two phases, liquid and vapor as shown in Fig. 2. The molar flow rate of saturated air is given by Eq. 3. Otherwise removed water trough vapor phase is limited by the saturation pressure of air stream. The available molar flow rate of air stream $\dot{n}_{\text {space }}$ is determined by Eq. 4.

$$
\dot{n}_{s a t}=\frac{\phi_{s} \cdot Q}{\gamma_{s} M_{r}}
$$
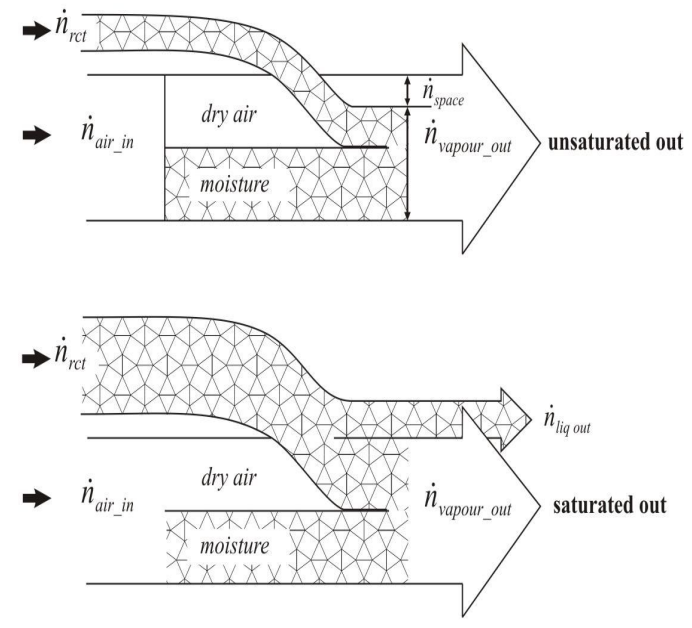

Fig 2. Water output phase

As long as the water input is not saturated, the removal of water in vapor phase is determined by Eq. 5. But the magnitude of $\dot{n}_{w, v a p}$ is limited by the $\dot{n}_{\text {space }}$ therefore the excess water will turn into liquid.

$$
\begin{aligned}
& \dot{n}_{\text {space }}=\dot{n}_{\text {sat }}-\dot{n}_{w, \text { in }} \\
& \dot{n}_{w, v a p}=\dot{n}_{w, i n}+\dot{n}_{r c t}
\end{aligned}
$$

The water liquid saturation level $(s)$ is defined as the volume fraction of the total void space of porous media occupied by the liquid phase. Hence, s is defined in Eq. 6 .

$$
s=\frac{V_{l i q}}{V_{t o t}}
$$

After receiving amount of water from fuel cell reaction and membrane side, liquid saturation level in CCL now is changed by Eq. 7 and Eq. 8. If there is no liquid water addition, the change of $\mathrm{s}$ is zero.

$$
\begin{aligned}
& \Delta s_{x, r c t}=\frac{\dot{n}_{w, l i q} M_{r}}{\rho \delta A \varepsilon} \\
& s_{x}=s_{0}+\Delta s_{x, r c t}
\end{aligned}
$$

Pasaogullari et al. [5] have studied about steady state water transportation in GDL of PEM fuel cell. In their work, it is seen that capillary transport is the dominant transport process to remove water from flooded GDLs.

Molar flow rate of the water transported by capillarity process is given by Eq. 9 . The liquid saturation change by capillarity process is given by Eq. 10 . 


$$
\begin{gathered}
\dot{n}_{\text {cap }}=s^{4}\left(1.417-4.240 s+3.789 s^{2}\right) \times \\
\frac{A \sigma \cos \left(\theta_{c}\right)(\varepsilon \kappa)^{0.5}}{M_{r} \mu \delta_{G D L}} \\
\Delta s_{x, \text { cap }}=\frac{\dot{n}_{\text {cap }} M_{r}}{\rho \delta A \varepsilon} \\
s_{x}=s_{0}+\Delta s_{x, \text { react }}-\Delta s_{x, \text { cap }}
\end{gathered}
$$

The water evaporation rate of system is defined by Eq. 12 and the liquid saturation change by evaporation process is given by Eq 13.

$$
\begin{aligned}
& \dot{n}_{\text {evap }}= \\
& \frac{h(4 s+2)(\varepsilon \delta A)^{2 / 3}\left|T_{l i q}-T_{\text {air }}\right|}{\lambda M_{r}} \\
& \Delta s_{x, \text { evap }}=\frac{\dot{n}_{\text {evap }} M_{r}}{\rho \delta A \varepsilon}
\end{aligned}
$$

The final liquid saturation becomes

$$
s_{x}=s_{0}+\triangle s_{x, r c t}-\triangle s_{x, c a p}-\triangle s_{x, e v a p}
$$

The vehicle power model used on this simulation is given by Eq. 15 until Eq. 18. $W_{\text {roll }}, \quad W_{\text {air resist }}, \quad W_{\text {kinetic }}$, and $W_{\text {total }}$ respectively are the power absorbed by rolling resistance, air resistance, kinetic power used and total power absorbed.

$$
\begin{aligned}
& W_{\text {roll }}=m_{v e} v_{v e} g C R F \\
& W_{\text {air resist }}=0.5 \rho_{\text {air }} v_{v e}^{3} c_{d r a g} A_{v e} \\
& W_{\text {kinetic }}=m_{v e} v_{v e} a_{v e}
\end{aligned}
$$

$$
W_{\text {total }}=W_{\text {roll }}+W_{\text {resist }}+W_{\text {kinetic }}
$$

\section{Simulation}

\begin{tabular}{|c|c|}
\hline Parameter & Value \\
\hline $\mathrm{Q}$ & $0.08 \mathrm{~m}^{3} / \mathrm{s}$ \\
\hline $\mathrm{R}$ & 8.314 \\
\hline A & $0.02 \mathrm{~m}^{2}$ \\
\hline$\delta_{C L}$ & $1.10^{-5} \mathrm{~m}$ \\
\hline$\delta_{G D L}$ & $3.10^{-4} \mathrm{~m}$ \\
\hline $\mathrm{N}$ & 448 \\
\hline$M_{r}$ & $18.0153 .10^{-3} \mathrm{~kg} / \mathrm{mo}$ \\
\hline$\rho$ & $971.8 \mathrm{Kg} / \mathrm{m}^{3}$ \\
\hline$c_{d}$ & 0.5 \\
\hline$\kappa$ & $1.810^{-18} \mathrm{~m}^{2}$ \\
\hline$\mu$ & $8.5510^{-4} \mathrm{~N} . \mathrm{s} / \mathrm{m}^{2}$ \\
\hline$\varepsilon$ & 0.6 \\
\hline$\sigma$ & $0.0625 \mathrm{~N} / \mathrm{m}$ \\
\hline$\theta_{c}$ & 120 \\
\hline$h$ & $105.28 \mathrm{~W} / \mathrm{m}^{2} \mathrm{~K}$ \\
\hline$\lambda$ & $2417.44 \mathrm{~kJ} / \mathrm{kg}$ \\
\hline
\end{tabular}

Driving cycles used in this simulation are based on light duty vehicles driving schedule by several standards. There are three driving cycles used in this simulation [6]. New York city cycle (NYCC), extra urban driving cycle (EUDC) and the Japan 10-15 mode cycles. Fig. 4 shows the speed profiles from all used driving cycle in this study. Table 1 shows the parameter used for this simulation

Table 1. Simulation parameters 

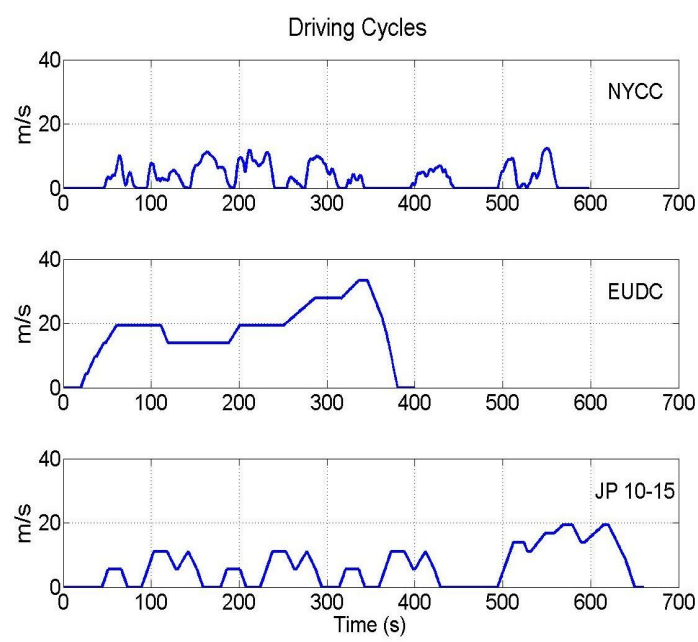

Fig 3. Speed profile for all driving cycles

\section{Results and discussions}

During the acceleration, the force was turned out to be positive. Since the speed is always positive, the power demand is positive as well and this power demand should be met by the power generation system. On the other hand, during the deceleration, the force and the power requested were negative.
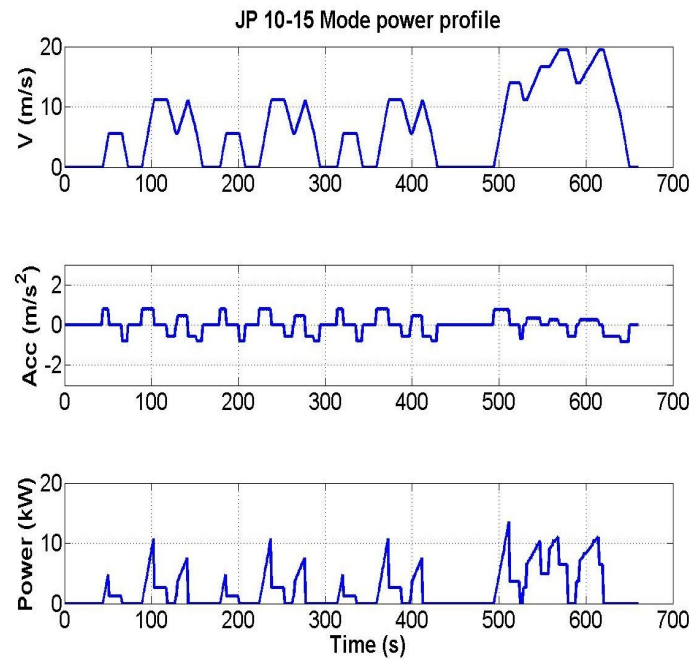

Fig 4. Power profiles for JP 10-15 Mode
Because this was handled by the braking system and then the power requested from the power generation subsystem was almost zero as shown in Fig 4. Also, the current densities of all driving cycles were shown in Fig 5.
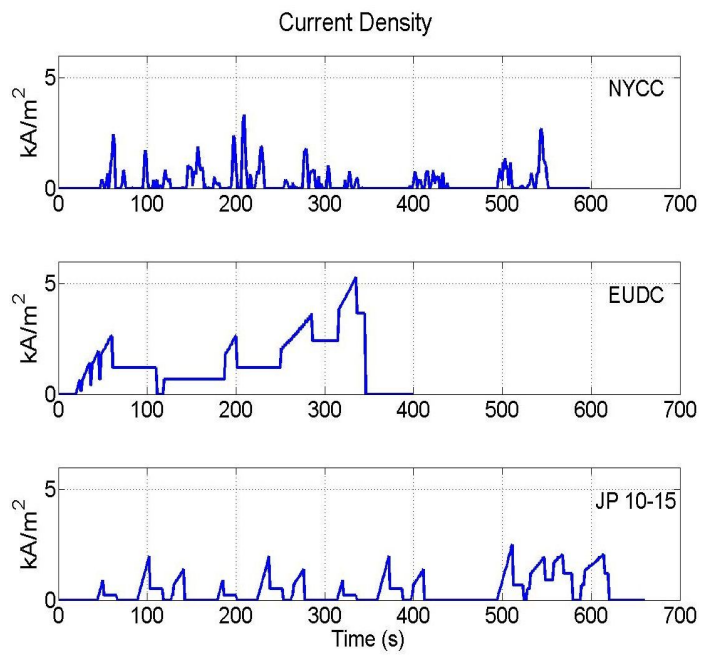

Fig 5. Current density profiles of all driving cycles

The simulation has started with low temperature and humidity ratio of the input air. The temperature under this condition is $40^{\circ} \mathrm{C}$ and the relative humidity is $50 \%$. With this condition, the humidity ratio after being transferred is equal to $23.5 \mathrm{~g} / \mathrm{kg}^{\prime}$. At low temperature the capability of the air stream to hold water is relatively low. Hence, the over-saturated stream tends to occur after receiving water from the fuel cell reaction as shown in Fig. 6. As long as the amount of water received by CCL is not larger than its maximum capability to hold water, the over-saturated stream will not occur.

Flooding phenomena is occurred in almost all profiles at low temperature, otherwise EUDC has the highest power load than other cycles. Therefore, the water 
addition is higher than its removal, which causes EUDC to have the highest liquid saturation level profile.

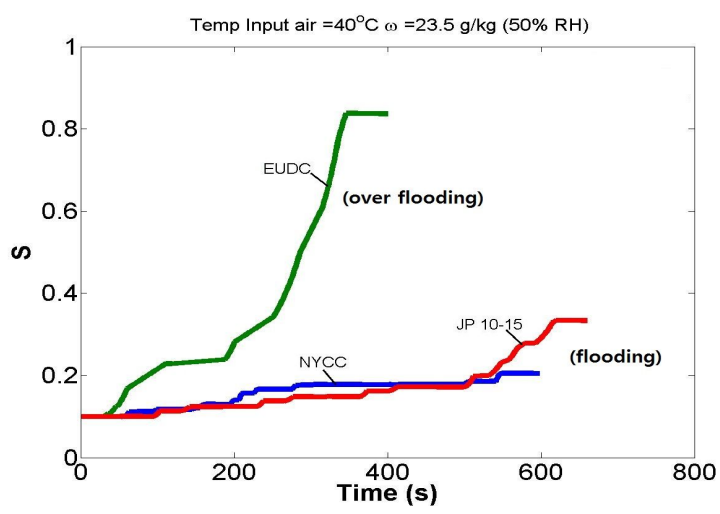

Fig 6. Current density profiles when flooding

Increasing the temperature of the air input from $40^{\circ} \mathrm{C}$ to $60^{\circ} \mathrm{C}$ will decrease the relative humidity from $50 \%$ to $18.5 \%$ with same humidity ratio $23.5 \mathrm{~g} / \mathrm{kg}$. In this condition, the capability of the air stream to hold more water is higher than the previous condition. This condition, however, makes the low load profile get dried. Under this condition, the capability of the air stream to carry out water is higher than before, but the evaporation rate is also high. As a result, the drying phenomenon has happened like as shown in Fig. 7.

Consequently, increasing the humidity ratio becomes the common method to avoid the drying phenomenon. The next simulation condition was done by increasing the humidity ratio of the input air as shown in Fig. 8. This figure shows the liquid saturation level when fuel cell was operated at $60^{\circ} \mathrm{C}$ of air with $67.9 \mathrm{~g} / \mathrm{kg}$ humidity ratio (50\% RH). In this condition, flooding in low load profiles such as NYCC and JP 10-15 can be avoided and over flooding in high load profiles (EUDC) can also be reduced.

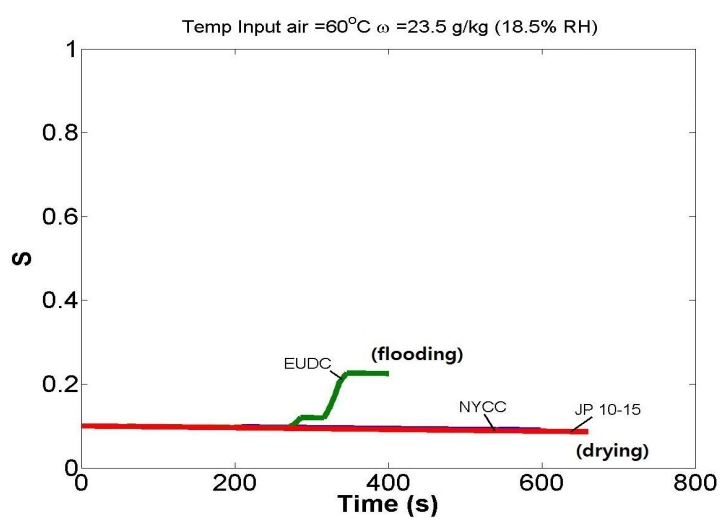

Fig 7. Current density profiles when drying

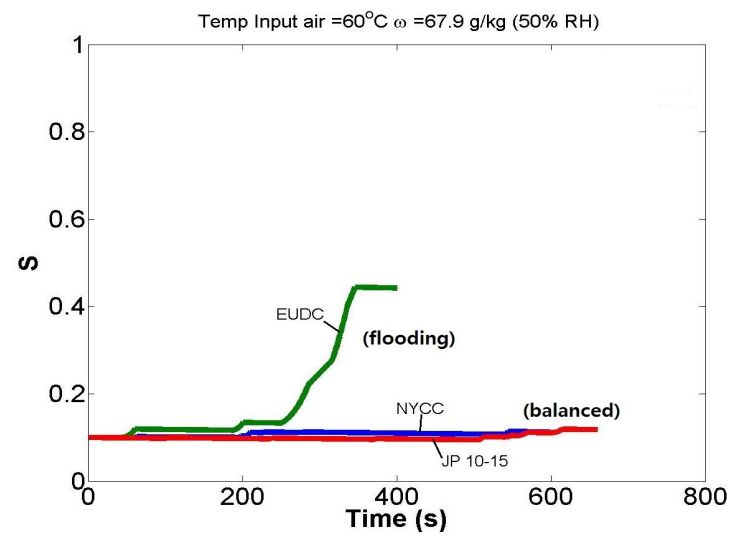

Fig 8. Current density profiles when balanced and flooding

\section{Conclusions}

This study has made the water transportation model of the PEM fuel cell and also the simulation using driving cycles. Due to the obtained water balance, a fuel cell with different dynamic load profile also requires different condition of temperature and humidity of air input. This means the proper condition for water management 
parameters will be different in every dynamic profiles. Therefore, the dynamic water management system is necessary. The results are the following;

(1) As long as the amount of water received by CCL is not larger than its maximum capability, the over-saturated stream will not occur.

(2) A dynamic power profile which has much accelerations needs more power. In this case, the water production is increased therefore the water removal rate should be increased to avoid flooding. In this paper, the water balance is obtained in input air condition $60^{\circ} \mathrm{C}$ temperature with $67.9 \mathrm{~g} / \mathrm{kg}$ humidity ratio (50\% $\mathrm{RH})$.

\section{References}

1. C.Y. Wang, Chem. Rev. 104(2004) 4727.

2. M.G. Izenson, R.W. Hill, Proceedings of the IMECE 2002, ASME International Mechanical Engineering Congress \& Exposition, p. 147, 2002

3. Mao L, Wang, C. Y., Journal of The Electrochemical Society, 154 (2) B139-B146, 2007

4. ASHRAE. Fundamentals, ASHRAE Inc., 2009

5. Pasaogullari Ugur, Wang, C. Y., Journal of The Electrochemical Society, 151 (3) A399-A406, 2004

6. United States The Environmental Protection Agency (US EPA) website, http://www. epa.gov/nvfel/testing/dynamometer.htm: accessed Sep. 2009 